\title{
CORPORATE GOVERNANCE DAN MANAJEMEN LABA PADA BEBERAPA PENELITIAN SKRIPSI PERGURUAN TINGGI, STUDI META ANALISIS
}

\author{
Angeline \\ Carmel Meiden \\ Institut Bisnis dan Informatika Kwik Kian Gie \\ angeline_ae@yahoo.com \\ carmel.meiden@kwikkiangie.ac.id
}

\begin{abstract}
Topic about corporate governance effect on earnings management has been researched by many researcher and still exist until now. The existing research provides both consistent and inconsistent results with different levels of significance. This study aims to integrate thesis results of higher Education related to the topic of corporate governance effect on earnings management in Indonesia period 2004-2014. Data collection method use observation method with as the output thesis. The sample of this research is 23 thesis student of higher education. The sampling technique is purposive sampling technique. Researcher use meta-analysis technique to integrate the result of the thesis research and show conclusions related to the effect of corporate governance on earnings management. The result of this research shows that managerial ownership,institutional ownership, the size of the board directors and the size of board commissioners effect earnings management. The correlation of the weak independent variable to the dependent variable is shown by the average correlation value below 0.25 . In addition, this study also proves that the validity of agency theory in several manufacturing companies, banking, LQ45 in the study period $2004-2014$.
\end{abstract}

Keywords: Meta Analysis, Earnings Management, Corporate Governance

\section{PENDAHULUAN}

\subsection{Latar Belakang Penelitian}

Berdasarkan kerangka konseptual, laporan keuangan merupakan suatu penyajian terstruktur dari posisi keuangan dan kinerja keuangan suatu entitas dengan tujuan untuk memberikan informasi mengenai posisi keuangan, kinerja keuangan, dan arus kas entitas yang bermanfaat bagi sebagian besar pengguna laporan keuangan dalam pembuatan keputusan ekonomik. Laporan keuangan juga menunjukkan hasil pertanggungjawaban manajemen atas penggunaan sumber daya yang dipercayakan. Agar dapat diandalkan, informasi dalam laporan keuangan harus menggambarkan dengan jujur transaksi serta peristiwa lainnya yang seharusnya disajikan atau yang secara wajar dapat diharapkan untuk disajikan (PSAK No. 1, IAI, 2014).

Laba dalam laporan keuangan merupakan salah satu parameter penting sebagai suatu informasi. Namun, seringkali tidak dipungkiri bahwa pelaporan laba pada beberapa entitas tidak disajikan dan tidak mencerminkan fakta yang sebenarnya mengenai kondisi ekonomi entitas tersebut. Laba yang seharusnya diharapkan dapat memberikan informasi untuk mendukung pengambilan keputusan menjadi diragukan kualitasnya. Laba yang tidak menunjukkan informasi yang sebenarnya tentang kinerja manajemen dapat menyesakan pihak pengguna laporan keuangan (Boediono, 2005: 173). Menurut Subramanyam dalam Siregar dan Utama (2005: 475), adanya fleksibilitas yang senantiasa terbuka dalam implementasi Prinsip Akuntansi yang Berlaku Umum (Generally Accepted Accounting Principles) menyebabkan manajemen dapat memilih kebijakan akuntansi dari berbagai pilihan kebijakan yang ada, sehingga pada gilirannya fleksibilitas tersebut memungkinkan dilakukannya pengelolaan laba (earnings management) oleh manajemen perusahaan. 
Manajemen laba merupakan suatu fenomena yang sukar untuk dihindari. Hal ini disebabkan adanya asimetri informasi antara manajer sebagai agent dan pemilik yang dalam hal ini adalah pemegang saham sebagai principal. Asimetri informasi ini muncul karena manajer lebih mengetahui informasi internal dan prospek perusahaan dimasa yang akan datang dibandingkan pemegang saham. Manajemen termotivasi untuk memperlihatkan kinerja yang baik dalam menghasilkan keuntungan atau laba yang maksimal bagi perusahaan sebagai bentuk tanggung jawabanya kepada para pemegang saham. Manajer dari suatu perusahaan memiliki kekuatan untuk memanipulasi informasi yang ada demi meningkatkan kesejahteraan dirinya sendiri dan bukan demi kesejahteraan para pemegang saham.

Salah satu hal yang menyebabkan terjadinya skandal manajemen laba pada perusahaan berkaitan dengan manipulasi laba adalah dikarenakan lemahnya tata kelola perusahaan (corporate governance). Corporate Governance adalah seperangkat aturan yang mendefinisikan hubungan antara pemegang saham, manajer, kreditor, pemerintah, karyawan dan stakeholder internal dan eksternal lainnya yang berkaitan dengan hak-hak mereka dan tanggung jawab, atau sistem dimana perusahaan diarahkan dan dikendalikan (FCGI, 2006). Corporate Governance ditujukan untuk membantu menyelaraskan kepentingan antara manajemen dengan kepentingan pemegang saham dan meningkatkan reabilitas informasi financial serta integritas proses pelaporan financial.

Kepemilikan saham oleh manajemen memiliki andil dalam mewujudkan tata kelola perusahaan yang baik. Dengan memperbesar kepemilikan saham perusahaan bagi manajemen (managerial ownership), kepentingan pemilik atau pemegang saham dapat disejajarkan dengan kepentingan manajemen (Jensen dan Meckling, 1976). Hasil penelitian Eny et al., (2015), menemukan adanya hubungan yang kuat antara kepemilikan manajerial terhadap manajemen laba. Dengan keikutsertaan manajer memiliki perusahaan, hal ini menyebabkan manajer melakukan tindakan yang akan memaksimumkan dalam pemberian informasi mengenai laba yang lebih jujur. Namun sebaliknya, menurut penelitian Christiantie dan Christiawan (2013), kepemilikan institusional tidak berpengaruh signifikan terhadap aktivitas manajemen laba.

Kepemilikan saham oleh investor institusional juga sebagai pihak yang dapat membantu menciptakan tata kelola perusahaan yang baik. Investor institusional merupakan investor yang dianggap sebagai investor cangih (sophisticated investors) yang tidak dengan mudah bisa dikelabui oleh tindakan manajemen dan seharusnya lebih dapat menggunakan informasi periode sekarang dalam memprediksi laba masa depan dibandingkan dengan investor non institusional (Siregar dan Utama, 2005). Dengan semakin kuatnya pengawasan akan mempersempit kesempatan manajemen untuk melakukan kecurangan. Menurut Sumanto dan Kiswanto (2014) dalam penelitiannya, kepemilikan institusional memiliki pengaruh terhadap manajemen laba. Semakin tinggi kepemilikan institusional dalam suatu perusahaan akan mampu mengurangi terjadinya manajemen laba. Namun dilain pihak, penelitian Mahariana dan Ramantha (2014) menyatakan bahwa kepemilikan institusional tidak memiliki pengaruh terhadap manajemen laba.

Menurut UU No. 40 tahun 2007 tentang perseroan terbatas pasal 1, direksi adalah organ perseroan yang berwenang dan bertanggung jawab penuh atas pengurusan perseroan untuk kepentingan perseroan sesuai dengan maksud dan tujuan perseroan serta mewakili perseroan, baik di dalam maupun di luar pengadilan sesuai dengan ketentuan anggaran dasar. Agar pelaksanaan tugas direksi dapat berjalan secara efektif, salah satu prinsip yang perlu dipenuhi adalah komposisi direksi harus sedemikian rupa sehingga memungkinkan pengambilan keputusan secara efektif, tepat, dan cepat, serta dapat bertindak independen (Komite Nasional Kebijakan Governance, 2006). Dewan direksi merupakan sistem manajemen yang bertanggung jawab dalam penyelenggaraan Good Corporate Governance untuk mencapai tujuan perusahaan. Aygun et al., (2014) menemukan bahwa ukuran dewan direksi berpengaruh terhadap manajemen laba. Hasil ini mengindikasikan bahwa ukuran dewan direksi yang besar dapat mengatur kebijakan di perusahaan dengan lebih efektif. Dengan ukuran dewan direksi yang besar diharapkan pengelolaan perusahaan akan lebih baik sehingga menurunkan tindakan manajemen laba. Hasil penelitian Aygun et al., (2014) tidak sejalan dengan hasil penelitian 
menurut Widyaningdyah (2001) yang tidak menemukan adanya hubungan signifikan antara ukuran dewan direksi terhadap manajemen laba.

Dewan komisaris memegang peranan yang sangat penting dalam perusahaan, terutama dalam pelaksanaan good corporate governance. Dewan komisaris adalah organ perseroan yang bertugas melakukan pengawasan secara umum dan/ atau khusus sesuai dengan anggaran dasar serta memberi nasihat kepada direksi (Komite Nasional Kebijakan Governance, 2006). Menurut Egon Zehnder dalam FCGI (2006), dewan komisaris merupakan inti dari corporate governance yang ditugaskan untuk menjamin pelaksanaan strategi perusahaan, mengawasi manajemen dalam mengelola perusahaan, serta mewajibkan terlaksananya akuntabilitas. Pada intinya, dewan komisaris merupakan suatu mekanisme mengawasi dan mekanisme untuk memberikan petunjuk dan arahan pada pengelola perusahaan. Mengingat manajemen yang bertanggungjawab untuk meningkatkan efisiensi dan daya saing perusahaan, sedangkan dewan komisaris bertanggungjawab untuk mengawasi manajemen, maka dewan komisaris merupakan pusat ketahanan dan kesuksesan perusahaan. Hasil penelitian Xie et al., (2003), menemukan bahwa makin banyak dewan komisaris maka pembatasan terhadap tindakan manajemen laba dapat dilakukan dengan lebih efektif. Dengan kata lain ukuran dewan komisaris berpengaruh terhadap manajemen laba. Sebaliknya menurut penelitian Ujiyantho dan Agus Pramuka (2007), ukuran dewan komisaris tidak berpengaruh terhadap manajemen laba.

Penelitian yang dilakukan oleh Eny et al., (2015) telah mengamati bahwa terdapat beberapa penelitian di Indonesia tentang pengaruh mekanisme corporate governance terhadap manajemen laba. Beberapa dari penelitian yang ada menunjukkan hasil yang konsisten maupun tidak konsisten dengan tingkat signifikansi yang berbeda-beda. Temuan dari penelitianpenelitian itu masih bervariasi dan masih terdapat pertentangan satu sama lain. Untuk menguji validitas dan daya generalisasi dari penelitian substansial yang sudah dilakukan dalam suatu bidang penelitian, perlu dilakukan sintesa dan menilai penelitian-penelitian empiris yang relevan dalam satu tema. Perlunya melakukan sintesa dan mengkaji penelitian-penelitian empiris terhadap manajemen laba yang relevan, karena penelitian-penelitian tersebut dilakukan di waktu yang berbeda-beda.

Untuk melakukan analisis secara kuantitatif terhadap beberapa hasil penelitian primer, Eny et al., (2015) melakukan pengujian dengan pendekatan meta analisis. Meta analisis dilakukan dengan tujuan untuk mengintegrasikan temuan-temuan yang ada atau dengan kata lain analisis dari analisis. Terkait fenomena dan latar belakang diatas, penelitian ini bermaksud untuk melakukan pengujian meta analisis terkait pengaruh corporate governance terhadap manajemen laba di Indonesia dengan mengambil hasil penelitian dari beberapa skripsi mahasiswamahasiswi Perguruan Tinggi periode 2004 - 2014.

\section{TINJAUAN PUSTAKA DAN PENGEMBANGAN HIPOTESIS 2.1. Teori Keagenan (Agency Theory)}

Teori keagenan (agency theory) menjelaskan hubungan antara agent (manajemen) dan principal (pemilik) yang disebut juga dengan hubungan keagenan (agency relationship). Jensen dan Meckling (1976) menyatakan bahwa hubungan keagenan merupakan suatu kontrak dimana salah satu atau lebih pemegang saham (principal) memerintahkan manajer (agent) untuk melakukan suatu jasa atas nama principal serta memberikan wewenang kepada agent untuk membuat keputusan yang terbaik bagi principal. Akan tetapi dalam pelaksanaannya, manajer tidak selalu bertindak berdasarkan kepentingan principal.

Menurut Scott (2015: 358), teori agensi merupakan cabang dari permainan teori yang mempelajari hubungan yang dapat memotivasi agent secara rasional untuk dapat berperan atas nama principal ketika kepentingan agent tersebut tidak bertentangan dengan kepentingan dari principal. Menurut teori keagenan (agency theory), adanya pemisahan antara kepemilikkan dan pengelolaan dalam suatu perusahaan dapat menimbulkan permasalahan keagenan (agency problem), yaitu munculnya konflik kepentingan antara pemilik atau pemegang saham dengan manajer sebagai pengelola perusahaan. 
Perilaku manipulasi oleh manajer yang berawal dari konflik kepentingan dan adanya ketidakseimbangan informasi (information asymmetry) dapat diminimumkan melalui suatu mekanisme monitoring yang bertujuan untuk menyelaraskan berbagai kepentingan tersebut, yaitu mekanisme corporate governance. Konsep corporate governance berkaitan dengan bagaimana para pemilik (pemegang saham) yakin bahwa manajer akan memberikan keuntungan bagi mereka, yakin bahwa manajer tidak akan melakukan kecurangan-kecurangan yang akan merugikan para pemegang saham. Dengan kata lain dengan penerapan corporate govenance diharapkan dapat berfungsi untuk menekankan atau menurunkan biaya keagenan (agency cost).

\subsection{Teori Akuntansi Positif ( Positive Accounting Theory)}

Teori akuntansi positif merupakan teori yang mengidentifikasi dan menganalisis berbagai bentuk praktik manajemen laba yang dilakukan oleh perusahaan. Teori ini secara khusus bertujuan untuk mengungkapkan pengaruh variabel-variabel ekonomi terhadap motivasi manajer untuk memilih suatu metode akuntansi. Teori ini mengasumsikan manajer selalu berfikir rasional dan akan memilih kebijakan akuntansi yang dapat memberi keuntungan kepada mereka.

Dalam teori akuntansi positif terdapat tiga hipotesis yang dijadikan dasar pemahaman tindakan manajemen laba (Watts dan Zimmerman, 1986) yaitu:

a. The Bonus Plan Hypothesis

Bonus Plan Hypothesis menyatakan bahwa "managers of firms with bonus plans are more likely to choose accounting procedures that shift reported earnings from future periods to the current period". Pada perusahaan yang memiliki rencana pemberian bonus, manajer perusahaan akan lebih memilih metode akuntansi yang dapat menggeser laba dari masa depan ke masa kini sehingga dapat menaikkan laba saat ini. Hal ini dikarenakan manajer lebih menyukai pemberian upah yang lebih tinggi untuk masa kini. Seandainya pada tahun tertentu laba sesungguhnya berada di bawah syarat untuk menerima bonus, maka manajer akan melakukan manajemen laba agar laba yang akan dilaporkan mencapai tingkat minimal untuk memperoleh bonus. Sebaliknya, jika pada tahun tertentu laba sesungguhnya jauh diatas jumlah yang disyaratkan untuk mendapat bonus, maka manajer akan mengelola/ mengatur agar laba yang dilaporkan tidak diatas batas laba tertinggi untuk mendapatkan bonus karena manajer tidak akan mendapat bonus tambahan. Kedua upaya ini dilakukan agar manajer selalu memperoleh bonus pada setiap periode.

b. The Debt to Equity Hypothesis (Debt Covenant Hypothesis)

Debt to Equity Plan Hypothesis menyatakan bahwa "the larger a firm's debt to equity ratio, the more likely the firm's manager is to select accounting procedures that shift reported earnings from future periods to the current period". Pada perusahaan yang mempunyai rasio debt to equity tinggi, manajer perusahaan cenderung menggunakan metode akuntansi yang dapat meningkatkan pendapatan atau laba. Perusahaan dengan rasio debt to equity yang tinggi akan mengalami kesulitan dalam memperoleh dana tambahan dari pihak kreditor bahkan perusahaan terancam melanggar perjanjian utang.

c. The Political Cost Hypothesis (Size Hypothesis)

Political Cost Hypothesis menyatakan bahwa "the larger the firm, the more likely the manager is to choose accounting procedures that defer reported earnings from current to future periods". Ada beberapa regulasi yang dikeluarkan pemerintah yang berkaitan dengan dunia usaha, salah satunya undang-undang perpajakan. Besar kecilnya pajak yang akan ditarik pemerintah tergantung pada besar kecilnya laba perusahaan. Hal ini membuat manager untuk melakukan tindakan manajemen laba dengan cara mengakui pendapatan periode berjalan menjadi pendapatan periode mendatang, sehingga laba perusahaan tidak terlalu tinggi yang membuat pajak yang dibayarkan juga lebih rendah. 


\subsection{Pengaruh kepemilikan manajerial terhadap manajemen laba}

Menurut (Eisenhardt, 1989) manusia pada umumnya mementingkan diri sendiri. Begitu pula sama halnya dengan manajer yang akan bertindak untuk memperoleh manfaat terutama bagi dirinya sendiri dengan cara melakukan manajemen laba. Perilaku manajemen laba sangat ditentukan oleh motivasi manajer perusahaan. Motivasi yang berbeda akan menghasilkan besaran manajemen laba yang berbeda. Oleh karena itu kepemilikan saham oleh pihak manajemen perusahaan dianggap berpengaruh terhadap tindakan manajemen laba.

Dilihat dari sisi/ konteks kepentingan sebagai principal, semakin tinggi manajer memiliki saham perusahaan di tempat ia bekerja, maka tindakan manajemen laba akan semakin rendah. Hal ini dikarenakan manajer juga memiliki kepentingan sebagai pemilik saham (principal) yang membutuhkan laporan keuangan yang akurat untuk ikut menentukan keputusan yang diambil dalam pengelolaan perusahaan. Dengan adanya pengambilan keputusan yang tepat, perusahaan akan mendapatkan keuntungan yang maksimal yang berdampak pada dividen yang diterima para pemegang saham termasuk manajer yang mempunyai kepemilikan saham. Pemikiran ini didukung dengan hasil penelitian Eny et al., (2015), Midiastuty dan Machfoedz (2003), Ujiyantho dan Agus Pramuka (2007).

Namun jika dilihat dari sisi/ konteks kepentingan bonus, walaupun manajer memiliki persentase saham yang tinggi, tindakan manajemen laba tetap akan tinggi. Hal ini dikarenakan manajer lebih cenderung untuk mementingkan bonus yang akan diterimanya atas tindakan manajemen laba yang ia lakukan. Bagi manajer, nilai bonus yang akan diterima dianggap lebih besar dari pada dividen atas kepemilikan sahamnya di perusaahaan ia berinvestasi sekaligus bekerja. Pemikiran ini didukung dengan hasil penelitian Boediono (2005) dan Aygun et al., (2014).

\subsection{Pengaruh kepemilikan institusional terhadap manajemen laba}

Kepemilikan institusional dianggap memiliki pengaruh terhadap tindakan manajemen laba oleh manajer. Dilihat dari sisi/ konteks kepemilikan jangka panjang, semakin tinggi kepemilikan saham oleh pihak institusional, semakin tinggi juga tingkatan manajemen laba. Hal ini dikarenakan beberapa pihak institusional cenderung mementingkan kelangsungan usahanya dengan ikut serta membeli saham perusahaan yang dapat mencukupi akan kebutuhan bahan baku usahanya. Pihak investor institusional lebih mementingkan keuntungan yang akan didapatkannya dari usaha jangka panjangnya dari pada hanya sekedar memikirkan tindakan manajemen laba yang dilakukan oleh manajemen perusahaan dimana tempat mereka menanamkan sahamnya. Pemikiran ini didukung dengan hasil penelitian Rajgopal et al., (1999) dan Aygun et al., (2014).

Dilihat dari sisi/ konteks persentase kepemilikan, semakin tinggi kepemilikan saham oleh pihak institusional, maka tindakan manajemen laba akan semakin rendah. Hal ini dikarenakan investor yang biasanya memiliki saham cukup besar dalam suatu perusahaan cenderung akan mencari informasi lebih banyak serta mengawasi tindakan-tindakan manajer sehingga akan mengurangi tindakan manajemen laba. Investor institusional akan melakukan monitoring secara efektif dan tidak akan mudah diperdaya dengan tindakan manipulasi yang dilakukan manajer. Menurut Wardhani (2006), adanya kepemilikan saham investor institusional yang tinggi ini maka pemegang saham institusional ini dapat menggantikan atau memperkuat fungsi monitoring dari dewan dalam perusahaan. Pemikiran ini didukung dengan hasil penelitian Tarjo (2008), Midiastuty dan Machfoedz (2003), serta Sumanto dan Kiswanto (2014).

\subsection{Pengaruh ukuran dewan direksi terhadap manajemen laba}

Dewan direksi memiliki wewenang dalam menetapkan kebijakan dan pedoman kerja sebagai acuan operasional perusahaan serta pengelolaan sumber daya perusahaan. Dalam suatu perusahaan jumlah atau komposisi dewan direksi disesuaikan dengan kebutuhan untuk menjalankan fungsi fiduciary dan memperhatikan efektivitas dalam pengambilan keputusan. 
Ukuran dewan direksi dianggap berpengaruh terhadap manajemen laba. Dilihat dari sisi/ konteks peran yang efektif, semakin besar ukuran dewan direksi dalam perusahaan, maka tindakan manajemen laba semakin kecil. Hal ini dikarenakan para dewan direksi dapat saling berkoordinasi secara efektif untuk menentukan kebijakan sebagai pedoman dalam mengelola perusahaan. Adanya kebijakan ketat yang ditetapkan dewan direksi membuat pihak manajer akan sulit untuk melakukan tindakan manajemen laba. Pemikiran ini didukung dengan hasil penelitian Aygun et al., (2014).

Dilihat dari sisi/ konteks peran yang tidak efektif, semakin besar ukuran dewan direksi dalam perusahaan, maka tindakan manajemen laba oleh manajer akan semakin tinggi. Hal ini dikarenakan ukuran dewan direksi yang terlalu besar membuat peran dewan direksi sulit berkoordinasi dan lebih lama dalam hal pengambilan keputusan sehingga manajer dapat memanfaatkan hal ini untuk melakukan tindakan manajemen laba. Pemikiran ini didukung dengan hasil penelitian Midiastuty dan Machfoedz (2003) dan Pradipta (2011).

\subsection{Pengaruh ukuran dewan komisaris terhadap manajemen laba}

Menurut KNKG (2006), anggota dewan komisaris harus profesional, yaitu berintegritas dan memiliki kemampuan sehingga dapat menjalankan fungsinya dengan baik termasuk memastikan bahwa direksi telah memperhatikan kepentingan semua pemangku kepentingan. Dewan komisaris yang memiliki fungsi monitoring dianggap berpengaruh terhadap tindakan manajemen laba yang dilakukan oleh pihak manajemen.

Dilihat dari sisi/ konteks peran yang efektif, semakin besar ukuran dewan komisaris dalam perusahaan, maka tindakan manajemen laba semakin kecil. Hal ini dikarenakan para dewan komisaris dapat memaksimalkan perannya dalam mengawasi manajer dalam mengelola perusahaan, sehingga manajer akan membuat laporan keuangan menjadi lebih kredibel dan takut jika melakukan manajemen laba. Pemikiran ini didukung dengan hasil penelitian Xie et al., (2003), Sumanto dan Kiswanto (2014).

Dilihat dari sisi/ konteks peran yang tidak efektif, semakin besar ukuran dewan komisaris dalam perusahaan, maka tindakan manajemen laba oleh manajer akan semakin tinggi. Hal ini dikarenakan ukuran dewan komisaris yang terlalu besar dapat membuatnya tidak efektif dan menyulitkan dalam menjalankan perannya diantaranya kesulitan dalam berkomunikasi dan mengkoordinir kerja dari masing-masing anggota dewan itu sendiri, kesulitan dalam mengawasi dan mengendalikan tindakan dari manajemen. Konsekuensinya, manajer dapat memanfasatkan kondisi ini untuk lebih leluasa dalam melakukan tindakan manajemen laba. Pemikiran ini didukung dengan hasil penelitian Nasution dan Setiawan (2007).

\subsection{Hipotesis Penelitian}

$\mathrm{Ha}_{1} \quad$ : Kepemilikan manajerial berpengaruh terhadap manajemen laba.

$\mathrm{Ha}_{2} \quad$ : Kepemilikan institusional berpengaruh terhadap manajemen laba.

$\mathrm{Ha}_{3}$ : Ukuran dewan direksi berpengaruh terhadap manajemen laba.

$\mathrm{Ha}_{4} \quad$ : Ukuran dewan komisaris berpengaruh terhadap manajemen laba.

\section{METODE PENELITIAN}

Obyek dalam penelitian ini adalah skripsi mahasiswa Perguruan Tinggi periode 2004-2014 terkait pengaruh corporate governance terhadap manajemen laba di Indonesia. Dalam penelitian ini, yang merupakan variabel dependen adalah manajemen laba. Sedangkan untuk variabel independen dalam penelitian ini adalah kepemilikan manajerial, kepemilikan institusional, ukuran dewan direksi dan ukuran dewan komisaris. Penelitian ini menggunakan teknik pengumpulan data dengan studi pengamatan (observasi) dan pencatatan atas output skripsi mahasiswa Perguruan Tinggi terkait topik pengaruh corporate governance terhadap manajemen laba di Indonesia dengan menggunakan periode penelitian antara tahun 2004 sampai dengan 2014, dimana data dikumpulkan dengan terlebih dahulu mencari judul skripsi di 
repository perpustakaan (http://repository.kwikkiangie.ac.id/) dan mengecek ketersediaan hard cover skripsi di perpustakaan Perguruan Tinggi.

Dalam penelitian ini, teknik pengambilan sampel yang digunakan adalah non-probabilistic sampling dengan metode purposive sampling, yang merupakan metode pengambilan sampel berdasarkan kriteria tertentu dengan tujuan untuk memperoleh sampel yang representatif sesuai dengan kriteria yang ditetapkan sehingga didapatkan sampel sebanyak 23 skripsi. Adapun kriteria-kriteria yang ditetapkan antara lain sebagai berikut:

a. Penelitian mahasiswa-mahasiswi Perguruan Tinggi dengan topik pengaruh corporate governance terhadap manajemen laba di Indonesia, dimana pencarian melalui repository perpustakaan sampai dengan tanggal 31 April 2017.

b. Penelitian dengan topik corporate governance terhadap manajemen laba di Indonesia yang terdapat variabel kepemilikan manajerial, kepemilikan institusional, ukuran dewan direksi dan ukuran dewan komisaris.

c. Penelitian yang merupakan skripsi bukan tesis.

d. Skripsi dengan periode penelitian antara 2004-2014.

e. Skripsi yang terdapat di perpustakaan Perguruan Tinggi yang datanya tersedia secara lengkap dan informasinya dapat digunakan untuk kebutuhan analisis.

\subsection{Teknik Analisis Data}

Teknik analisis data yang digunakan dalam penelitian ini bersifat kuantitatif dengan menggunakan metode meta analisis. Menurut Nindrea (2016), meta analisis merupakan suatu metode yang melakukan analisis secara mendalam terhadap suatu topik dari beberapa penelitian yang dijadikan satu sehingga menyerupai sebuah penelitian besar dengan menggunakan analisis statistik. Prosedur yang digunakan dala penelitian ini mengikuti apa yang telah dilakukan oleh penelitian Eny (2013). Tahapan teknik meta analisis dalam penelitian ini meliputi:

a. Mengkonversi atau melakukan transformasi statistik ukuran efek/ hasil statistik dari tiap-tiap penelitian menjadi suatu ukuran bersama yaitu (r), dimana ukuran efek tersebut (r) akan digunakan untuk melakukan pengakumulasian, perbandingan dan integrasi.

b. Ukuran efek dari tiap-tiap penelitian akan ditransformasi menjadi (r) dengan menggunakan prosedur rumus dari Hunter \& Schmidt dalam Lyons (2000), dalam penelitian ini hasil statistik yang akan dikonversi atau ditransformasi menjadi (r) yaitu $t$ statistik dengan rumus:

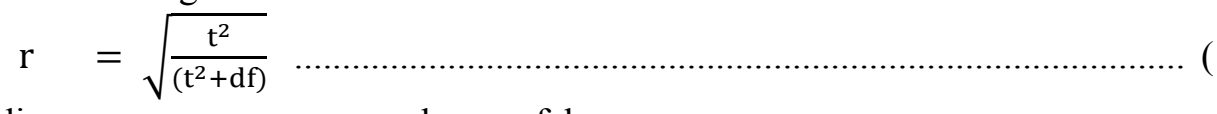

$$
\begin{aligned}
& \text { dimana : } r=\text { ukuran efek } \\
& \mathrm{t} \quad=\text { hasil } \mathrm{t} \text { statistik } \\
& \text { df } \quad=\text { degree of freedom }
\end{aligned}
$$

c. Mengakumulasi ukuran efek dan menghitung korelasi rata-rata (average correlation coefficient $(\bar{r}))$ dengan rumus:

$$
\begin{aligned}
& \overline{\mathrm{r}} \quad=\frac{\Sigma(\mathrm{Ni} \mathrm{ri})}{\Sigma \mathrm{Ni}} \text {..... } \\
& \text { dimana: } \quad \stackrel{\bar{r}}{\Sigma N i}=\text { korelasi rata-rata } \\
& \mathrm{Ni} \quad=\text { jumlah subjek (sampel) dalam penelitian } \\
& \text { ri }=\text { ukuran efek untuk tiap-tiap penelitian }
\end{aligned}
$$

d. Menghitung total variance yang diamati dengan rumus:

$$
\begin{aligned}
& \mathrm{S}_{\mathrm{r}}^{2}=\frac{\sum\left[\mathrm{N}_{\mathrm{i}}\left(\mathrm{r}_{\mathrm{i}}-\overline{\mathrm{r}}\right)^{2}\right]}{\sum \mathrm{N}_{\mathrm{i}}} \\
& \text { dimana: } \mathrm{S}_{\mathrm{r}}^{2} \quad=\text { total variance yang diamati } \\
& \overline{\mathrm{r}}=\text { korelasi rata-rata } \\
& \mathrm{Ni}=\text { jumlah subjek (sampel) dalam penelitian }
\end{aligned}
$$


ri $\quad=$ ukuran efek untuk tiap-tiap penelitian

e. Menghitung sampling error variance dengan rumus:

$$
\begin{aligned}
& \mathrm{S}_{\mathrm{e}}^{2}=\frac{\left(1-\overline{\mathrm{r}}^{2}\right)^{2} \mathrm{~K}}{\Sigma \mathrm{N}_{\mathrm{i}}} \text {. } \\
& \text { dimana: } \mathrm{S}_{\mathrm{e}}^{2} \quad=\text { sampling error variance } \\
& \overline{\mathrm{r}} \quad=\text { korelasi rata-rata } \\
& \mathrm{Ni}=\text { jumlah subjek (sampel) dalam penelitian } \\
& \mathrm{K}=\text { jumlah penelitian dalam analisis }
\end{aligned}
$$

f. Menghitung variance populasi sesungguhnya dengan rumus:

$$
\begin{aligned}
& \mathrm{S}_{\mathrm{p}}^{2}=\mathrm{S}_{\mathrm{r}}^{2}-\mathrm{S}_{\mathrm{e}}^{2} \\
& \text { dimana: } \quad \mathrm{S}_{\mathrm{p}}^{2} \quad=\text { variance populasi sesungguhnya } \\
& \mathrm{S}_{\mathrm{r}}^{2}=\text { total variance yang diamati } \\
& \mathrm{S}_{\mathrm{e}}^{2} \quad=\text { sampling error variance }
\end{aligned}
$$

g. Pengujian Hipotesis

Pengujian hipotesis dilakukan dengan menggunakan pendekatan sesuai uji Mann Whitney Test. Salah satu diantaranya yaitu uji Z pada tingkat interval keyakinan 95 persen (confidence interval, $\alpha$ ) dengan formula sebagai berikut:

$\left[\underline{\mathrm{r}}-\mathrm{S}_{\mathrm{P}}^{2} \mathrm{Z} \alpha ; \overline{\mathrm{r}}+\mathrm{S}_{\mathrm{P}}^{2} Z \alpha\right]=\left[\overline{\mathrm{r}}-\mathrm{S}_{\mathrm{P}}^{2}(1,96) ; \underline{\mathrm{r}}+\mathrm{S}_{\mathrm{P}}^{2} \mathrm{Z}(1,96)\right]$

Kriteria menerima atau mendukung hipotesis dengan menggunakan derajat kepercayaan $5 \%$, jika $\mathrm{r}$ hitung $>\mathrm{r}$ tabel, hipotesis tidak ditolak, artinya variabel independen tersebut berpengaruh secara signifikan terhadap variabel dependen.

Nilai $r$ berkisar antara -1 sampai dengan +1 termasuk 0 , semakin besar nilai $r$ (mendekati angka 1), maka semakin kuat (erat) pengaruh variabel independen terhadap variabel dependen. Sebaliknya, semakin kecil nilai korelasi (mendekati angka 0), maka semakin lemah pengaruh variabel independen terhadap variabel dependen. Nilai 0 berarti tidak ada pengaruh variabel independen terhadap variabel dependen (Sarwono, 2011).

\section{HASIL DAN PEMBAHASAN}

\subsection{Hasil Uji Meta Analisis}

Hasil meta analisis dari total sampel kepemilikan manajerial, kepemilikan institusional, ukuran dewan direksi dan ukuran dewan komisaris sebagai proksi dari corporate governance menunjukkan bahwa: Untuk variabel kepemilikan manajerial terdapat 19 studi yang dianalisis. Hasil penelitian meta analisis dapat di lihat di lampiran 1. Hasil meta analisis mengindikasikan bahwa kepemilikan manajerial mempengaruhi manajemen laba secara signifikan, tetapi memiliki korelasi yang lemah, hal ini terlihat dari mean correlation $(\overline{\mathrm{r}})=0.0950$ dengan confidence interval $95 \%$ antara $0.0934 ; 0.0967$. Hasil ( $(\overrightarrow{\mathrm{r}})$ hitung yang lebih besar dari $\mathrm{r}$ tabel menunjukkan pengaruh yang signifikan, hal ini mendukung hipotesis bahwa kepemilikan manajerial berpengaruh terhadap manajemen laba.

Hasil meta analisis sebanyak 20 studi menunjukkan adanya korelasi kepemilikan institusional terhadap manajemen laba, didapatkan nilai mean correlation $(\overline{\mathrm{r}})=0.0990$ dengan confidence interval 95\% antara 0.0973; 0.1007. Hasil ( $(\overline{\mathrm{r}})$ hitung yang lebih besar dari $\mathrm{r}$ tabel menunjukkan pengaruh yang signifikan namun lemah dari kepemilikan institusional terhadap manajemen laba. Hal ini mendukung hipotesis yang diajukan bahwa kepemilikan institusional berpengaruh terhadap manajemen laba.

Analisis terhadap 7 studi yang meneliti ukuran dewan direksi terhadap manajemen laba, menghasilkan nilai mean correlation $(\bar{r})=0.0643$ dengan confidence interval $95 \%$ antara $0.0595 ; 0.0690$. Hasil tersebut menunjukkan adanya pengaruh signifikan ukuran dewan direksi 
terhadap manajemen laba dengan korelasi yang lemah. Hasil (ṛ̂) hitung yang lebih besar dari $r$ tabel menunjukkan pengaruh yang signifikan. Temuan ini mendukung hipotesis bahwa ukuran dewan direksi berpengaruh terhadap manajemen laba.

Meta analisis pengaruh ukuran dewan komisaris melibatkan 9 studi dengan hasil mean correlation $(\overline{\mathrm{r}})=0.0714$, dimana confidence interval $95 \%$ antara $0.0706 ; 0.0722$. Hasil $(\overline{\mathrm{r}})$ hitung yang lebih besar dari $r$ tabel menunjukkan pengaruh yang signifikan. Temuan tersebut memberi bukti terhadap hipotesis bahwa ukuran dewan komisaris berpengaruh terhadap manajemen laba dapat diterima. Namun demikian, kekuatan variabel ukuran dewan komisaris ini memiliki korelasi yang rendah terhadap manajemen laba.

Hasil ringkasan meta analisis secara keseluruhan pengaruh corporate governance (kepemilikan manajerial, kepemilikan institusional, ukuran dewan direksi dan ukuran dewan komisaris) terhadap manajemen laba di Indonesia nampak pada tabel 4.1.

Tabel 4.1

Ringkasan Hasil Uji Hipotesis Meta - Analisis

\begin{tabular}{|c|c|c|c|c|c|c|c|}
\hline H & $\begin{array}{c}\text { Sampel/ } \\
\text { Studi }\end{array}$ & $\begin{array}{c}\text { Variabel } \\
\text { Dependen }\end{array}$ & $\begin{array}{c}\text { Variabel } \\
\text { Independen }\end{array}$ & $\begin{array}{c}\text { Mean } \\
\text { Corelation } \\
(\overline{\mathbf{r}}), \\
\text { r hitung }\end{array}$ & $\begin{array}{c}r \\
\text { tabel }\end{array}$ & Hasil & Ket. \\
\hline $\mathrm{H}_{\mathrm{a}} 1$ & $\begin{array}{l}3592 \\
/ 19\end{array}$ & $\begin{array}{l}\text { Manj. Laba } \\
\text { Discretionary } \\
\text { accrual }\end{array}$ & $\begin{array}{l}\text { Kepemilikan } \\
\text { Manajerial }\end{array}$ & 0.0950 & 0.0327 & $\begin{array}{l}\text { Signifikan } \\
\text { (lemah) }\end{array}$ & Didukung \\
\hline $\mathrm{H}_{\mathrm{a}} 2$ & $\begin{array}{l}3459 \\
/ 20\end{array}$ & $\begin{array}{l}\text { Manj. Laba } \\
\text { Discretionary } \\
\text { accrual }\end{array}$ & $\begin{array}{l}\text { Kepemilikan } \\
\text { Institusional }\end{array}$ & 0.0990 & 0.0333 & $\begin{array}{l}\text { Signifikan } \\
\text { (lemah) }\end{array}$ & Didukung \\
\hline $\mathrm{H}_{\mathrm{a}} 3$ & $\begin{array}{l}1444 \\
/ 7\end{array}$ & $\begin{array}{l}\text { Manj. Laba } \\
\text { Discretionary } \\
\text { accrual }\end{array}$ & $\begin{array}{l}\text { Ukuran } \\
\text { Dewan } \\
\text { Direksi }\end{array}$ & 0.0643 & 0.0516 & $\begin{array}{l}\text { Signifikan } \\
\text { (lemah) }\end{array}$ & Didukung \\
\hline $\mathrm{H}_{\mathrm{a}} 4$ & $\begin{array}{l}1984 \\
19\end{array}$ & $\begin{array}{l}\text { Manj. Laba } \\
\text { Discretionary } \\
\text { accrual }\end{array}$ & $\begin{array}{l}\text { Ukuran } \\
\text { Dewan } \\
\text { Komisaris }\end{array}$ & 0.0714 & 0.0440 & $\begin{array}{l}\text { Signifikan } \\
\text { (lemah) }\end{array}$ & Didukung \\
\hline
\end{tabular}

Sumber : olah statistik

\subsection{PEMBAHASAN}

Berdasarkan penelitian yang telah dilakukan, maka peneliti mencoba untuk menjelaskan hasil penelitian untuk menjawab batasan masalah yang tercantum pada bab I. Pembahasannya sebagai berikut:

\subsubsection{Pengaruh Kepemilikan Manajerial terhadap Manajemen Laba}

Corporate governance dalam konteks manajerial berkaitan dengan opportunistic behavior, dimana sesuai dengan teori agensi yang masih berlaku sampai saat ini bahwa pihak manajer memiliki kepentingannya sendiri di dalam perusahaan. Total sampel meta analisis membuktikan bahwa tidak tolak hipotesis 1 . Hal ini menunjukkan bahwa adanya pengaruh kepemilikan manajerial terhadap manajemen laba. 
Jika dilihat dari sisi/ konteks kepentingan manajer sebagai principal, semakin tinggi kepemilikan manajerial, maka tindakan manajemen laba semakin rendah karena manajer akan menyelaraskan kepentingannya sebagai pemegang saham (principal). Sedangkan jika dilihat dari sisi/ kepentingan bonus, walaupun kepemilikan manajerial di dalam perusahaan tinggi, tindakan manajemen laba tetap akan tinggi karena manajer lebih mementingkan bonus yang diterima atas tindakan manajemen laba.

Hal ini mengkonfirmasi bahwa meskipun jumlah kepemilikan manajerial sama-sama tinggi, jika dilihat dari sisi/ konteks yang berbeda yaitu kepentingan sebagai principal dan kepentingan bonus, maka tindakan manajemen laba yang dihasilkan akan berbeda. Hasil penelitian ini sejalan dengan meta analisis yang dilakukan oleh Eny et al., (2015) yang menemukan adanya pengaruh kepemilikan manajerial (dilihat dari sisi kepentingan) yang signifikan terhadap manajemen laba. Kepemilikan manajerial suatu perusahaan memang diharapkan berperan dalam menyelarasakan kepentingan principal dan agent.

\subsubsection{Pengaruh Kepemilikan Institusional terhadap Manajemen Laba}

Berdasarkan hasil pengujian meta analisis dapat disimpulkan bahwa kepemilikan institusional berpengaruh terhadap manajemen laba, sehingga hipotesis 2 tidak ditolak. Jika dilihat dari sisi/ konteks kepemilikan jangka panjang, semakin tinggi kepemilikan saham oleh pihak institusional, semakin tinggi juga tingkatan manajemen laba. Hal ini dikarenakan beberapa pihak institusional menanamkan sahamnya pada perusahaan sumber bahan bakunya untuk menjaga kelangsungan usahanya. Pihak investor institusional lebih mementingkan keuntungan yang akan didapatkannya dari usaha jangka panjangnya dari pada hanya sekedar memikirkan tindakan manajemen laba yang dilakukan oleh manajemen perusahaan dimana tempat mereka menanamkan sahamnya.

Jika dilihat dari sisi/ konteks persentase kepemilikan, semakin tinggi kepemilikan saham oleh pihak institusional, maka tindakan manajemen laba akan semakin rendah. Hal ini dikarenakan investor yang biasanya memiliki saham cukup besar dalam suatu perusahaan cenderung akan mencari informasi lebih banyak serta mengawasi tindakan-tindakan manajer sehingga akan mengurangi tindakan manajemen laba.

Kedua sisi/ konteks yang berbeda ini mengkonfirmasi bahwa meskipun jumlah kepemilikan institusional sama-sama tinggi, tindakan manajemen laba yang dihasilkan dapat berbeda. Penelitian yang dilakukan Eny et al., (2015) juga menunjukkan bahwa kepemilikan perusahaan berpengaruh terhadap manajemen laba. Dalam penelitian Eny et al., (2015) memberikan penjelasan lain, bahwa kepemilikan saham institusional yang cukup besar dapat mencerminkan kekuasaan, sehingga memiliki kemampuan untuk melakukan intervensi. Akibatnya, manajer terpaksa melakukan tindakan manajemen laba demi untuk memenuhi kepentingan pihak tertentu salah satunya pemilik.

\subsubsection{Pengaruh Ukuran Dewan Direksi terhadap Manajemen Laba}

Berdasarkan hasil penelitian meta analisis dapat disimpulkan bahwa ukuran dewan direksi berpengaruh terhadap manajemen laba, sehingga hipotesis 3 tidak ditolak. Jika dilihat dari sisi/ konteks peran yang efektif, semakin besar ukuran dewan direksi dalam perusahaan, maka tindakan manajemen laba semakin kecil, karena para dewan direksi dapat saling berkoordinasi untuk menentukan kebijakan yang ketat sebagai pedoman dalam mengelola perusahaan yang membuat pihak manajer akan sulit untuk melakukan tindakan manajemen laba. Sedangkan jika dilihat dari sisi/ konteks peran yang tidak efektif, semakin besar ukuran dewan direksi dalam perusahaan, maka tindakan manajemen laba oleh manajer akan semakin tinggi.

Hal ini dikarenakan ukuran dewan direksi yang terlalu besar membuat peran dewan direksi sulit berkoordinasi dan memakan waktu lebih lama dalam hal pengambilan keputusan sehingga manajer dapat memanfaatkan hal ini untuk melakukan tindakan manajemen laba. Hal ini 
mengkonfirmasi bahwa meskipun ukuran dewan direksi sama-sama tinggi, jika dilihat dari sisi/ konteks peran yang berbeda yaitu efektif dan tidak efektif, maka tindakan manajemen laba yang dihasilkan juga akan berbeda.

Dalam penelitian meta analisisnya, Eny et al., (2015) tidak melakukan pengujian variabel ukuran dewan direksi terhadap manajemen laba. Namun penelitian variabel ini didukung dengan penelitian Aygun et al., (2014), Pradipta (2011), Midiastuty dan Machfoedz (2003) yang membuktikan bahwa ukuran dewan direksi berpengaruh terhadap manajemen laba.

\subsubsection{Pengaruh Ukuran Dewan Komisaris terhadap Manajemen Laba}

Adanya dewan komisaris dalam hubungan keagenan antara manajerial dan pemilik saham diharapkan dapat menekan perilaku oportunis manajer. Dewan komisaris diharapkan perlindungan bagi para pemegang saham untuk menjaga kredibilitas laporan keuangan dengan cara mengawasi kualitas informasinya.

Berdasarkan hasil penelitian dapat disimpulkan bahwa ukuran dewan komisaris berpengaruh terhadap manajemen laba, sehingga hipotesis 4 tidak ditolak. Jika di lihat dari sisi/ konteks peran yang efektif, semakin besar ukuran dewan komisaris dalam perusahaan, maka tindakan manajemen laba semakin kecil karenak para dewan komisaris dapat memaksimalkan perannya dalam mengawasi manajer dalam mengelola perusahaan.

Sedangkan jika dilihat dari sisi/ konteks peran yang tidak efektif, semakin besar ukuran dewan komisaris dalam perusahaan, maka tindakan manajemen laba oleh manajer akan semakin tinggi. Hal ini dikarenakan ukuran dewan komisaris yang terlalu besar dapat membuatnya tidak efektif dan menyulitkan dalam menjalankan perannya diantaranya kesulitan dalam berkomunikasi dan mengkoordinir kerja dari masing-masing anggota dewan itu sendiri.

Hal ini mengkonfirmasi bahwa meskipun ukuran dewan komisaris sama-sama tinggi, jika dilihat dari sisi/ konteks peran yang berbeda yaitu efektif dan tidak efektif dalam hal pengawasan, maka tindakan manajemen laba yang dihasilkan juga akan berbeda. Penelitian yang dilakukan oleh Eny et al., (2015) juga menyatakan bahwa peran yang efektiflah yang dianggap sebagai mekanisme pengendalian dan pengawasan terhadap manajemen yang berpijak pada nilai, norma dan kepercayaan yang diterima yang akan membuat tindakan manajemen laba dapat diminimalisir.

\section{SIMPULAN DAN SARAN}

Berdasarkan uraian yang telah dikemukakan pada bab-bab sebelumnya, maka kesimpulan yang dapat diambil melalui hasil integrasi dari beberapa studi melalui meta analisis membuktikan adanya pengaruh kepemilikan manajerial, kepemilikan institusional, ukuran dewan direksi dan ukuran dewan komisaris terhadap manajemen laba pada perusahaanperusahaan di Indonesia.

Berdasarkan penelitian yang telah dilakukan, peneliti memberikan beberapa saran. Bagi investor diharapkan lebih berhati-hati dalam menginvestasaikan modalnya, karena tidak semua laporan keuangan yang disajikan perusahaan mencerminkan keadaan perusahaan yang sesungguhnya. Bagi perusahaan diharapkan dapat memperhatikan kepemilikan manajerial, kepemilikan institusional, ukuran dewan direksi dan ukuran dewan komisaris dalam perusahaan sesuai kebutuhan sehingga dapat memberikan manfaat yang optimal dan dapat meminimalisir tindakan manajemen laba dalam perusahaan. Bagi peneliti selanjutnya diharapkan dapat memperpanjang periode penelitian, menggunakan periode terbaru, menggunakan variabel independen lainnya, serta meneliti dengan menggunakan sampel jurnal terpublikasi yang datanya lengkap dan dapat diolah. 


\section{DAFTAR PUSTAKA}

Aygun, M., Ic, S. dan Sayim, M. (2014), The Effects of Corporate Ownership Structure and Board Size on Earnings Management: Evidence from Turkey, International Journal of Business and Management Vol 9 (12), pp. 123-132.

Boediono, G. S. (2005), Kualitas Laba: Studi Pengaruh Mekanisme Corporate Governance dan Dampak Manajemen Laba dengan Menggunakan Analisis Jalur, Simposium Nasional Akuntansi VIII Solo, pp. 172-194.

Christiantie, J. dan Christiawan, Y. J. (2013), Analisis Pengaruh Mekanisme Corporate Governance dan Reputasi KAP terhadap Aktivitas Manajemen Laba, Business Accounting Review 1.

Eisenhardt, K. M. (1989), Agency Theory: An Assessment and Review, Academy of Management Review, 14 No. 1, pp. 57-74.

Eny, N. (2013), Analisis-Meta: Faktor-Faktor yang Mempengaruhi Manajemen Laba di Indonesia. Disertasi, Tidak dipublikasikan.

Eny, N. et al. (2015), Meta Analysis: Corporate Governance dan Manajemen Laba di Indonesia, Simposium Nasional Akuntansi XVIII.

FCGI (2006), Peranan Dewan Komisaris dan Komite Audit dalam Pelaksanaan Corporate Governance ( Tata Kelola Perusahaan ), p. 45.

Kian gielkatan Akuntan Indonesia (2014), Pernyataan Standar Akuntansi Keuangan Per Efektif 1 Januari 2015. Jakarta: Dewan Standar Akuntansi Keuangan.

Jensen, M. C. dan Meckling, W. H. (1976), Theory of The Firm: Managerial Behavior, Agency Costs and Ownership Structure, Journal of Financial Economics, 3, pp. 305-360.

Komite Nasional Kebijakan Governance (2006), Pedoman Umum Good Corporate Governance Indonesia', Pedoman Umum Good Corporate Governance Indonesia, p. 30.

Lyons, L. C. (2000), Meta-analysis: Methods of Accumulating Results Across Research Domains, Retrieved February. Washington DC.

Mahariana, I. D. G. P. dan Ramantha, I. W. (2014), Pengaruh Kepemilikan Manajerial dan Kepemilikan Institusional pada Nilai Perusahaan Manufaktur di Bursa Efek Indonesia, E-Jurnal Akuntansi Universitas Udayana, pp. 519-528.

Midiastuty, P. P. dan Machfoedz, M. (2003), Analisis Hubungan Mekanisme Corporate Governance dan Indikasi Manajemen Laba, Simposium Nasional Akuntansi VI.

Nasution, M. dan Setiawan, D. (2007), Pengaruh Corporate Governance Terhadap Manajemen Laba Di Industri Perbankan Indonesia, Simposium Nasional Akuntansi X, (Juli), pp. 126.

Nindrea, R. D. (2016), Pengantar Langkah-Langkah Praktis Studi Meta Analisis. Yogyakarta: Goysen Publishing. 
Pradipta, A. (2011), Analisis Pengaruh dari Mekanisme Corporate Governance terhadap Manajemen Laba, Jurnal Bisnis dan Akuntansi, 13, pp. 93-106.

Rajgopal, S., Venkatachalam, M. dan Jiambalvo, J. (1999), Is Institutional Ownership Associated with Earnings Management and the Extent to which Stock Price Reflect Future Earnings?

Republik Indonesia (2007), Undang-Undang Republik Indonesia No 40. Jakarta: Dewan Perwakilan Rakyat.

Sarwono, J. (2011), Metode Penelitian Kuantitatif \& Kualitatif. Yogyakarta: Graha Ilmu.

Scott, W. R. (2009), Financial accounting theory. Fifth Edit. Canada: Pearson.

Scott, W. R. (2015), Financial Accounting Theory. Seventh Ed. Canada: Pearson.

Siallagan, H. dan Machfoedz, M. (2006), Mekanisme Corporate Governance, Kualitas Laba dan Nilai Perusahaan, Simposium Nasional Akuntansi 9 Padang.

Siregar, S. V. N. P. dan Utama, S. (2005), Pengaruh Struktur Kepemilikan, Ukuran Perusahaan, dan Praktek Corporate Governance terhadap Pengelolaan Laba (Earnings Management), Simposium Nasional Akuntansi VIII Solo.

Sumanto, B. dan Kiswanto, A. (2014), Pengaruh Kepemilikan Institusional Dan Ukuran Dewan Komisaris Terhadap Manajemen Laba, Accounting Analysis Journal, 3(1), pp. 44-52.

Tarjo (2008), Pengaruh Konsentrasi Kepemilikan Institusional dan Leverage terhadap Manajemen Laba, Nilai Pemegang Saham serta Cost of Equity Capital.

Ujiyantho, M. A. dan Agus Pramuka, B. (2007), Mekanisme Corporate Governance, Manajemen Laba dan Kinerja Keuangan (Studi pada Perusahaan Go Publik Sektor Manufaktur), Simposium Nasional Akuntansi X.

Wardhani, R. (2006), Mekanisme Corporate Governance Dalam Perusahaan yang Mengalami Permasalahan Keuangan, Simposium Nasional Akuntansi 9 Padang.

Watts, R. L. dan Zimmerman, J. L. (1986), Positive Accounting Theory. New Jersey: PrenticeHall, Inc.

Widyaningdyah, A. U. (2001), Analisis Faktor-Faktor Yang Berpengaruh Terhadap Earnings Management Pada Perusahaan Go Public Di Indonesia, Jurnal Akuntansi dan Keuangan, 3 No. 2(November) pp.89-101.

Xie, B., Davidson, W. N. dan Dadalt, P. J. (2003), Earnings Management and Corporate Governance: The Role of the Board and the Audit Committee, Journal of Corporate Finance, 9, pp. 295-316. 
Hasil Meta Analisis

Pengaruh Corporate Governance terhadap Manajemen Laba di Indonesia

\begin{tabular}{|c|c|c|c|c|c|c|c|c|c|c|c|}
\hline No & $\begin{array}{l}\text { Variabel } \\
\text { Explanatory }\end{array}$ & $\mathrm{N}$ & Studi & $\mathrm{r}$ & $S_{r}^{2}$ & $S_{e}^{2}$ & $S_{P}^{2}$ & \multicolumn{2}{|c|}{$\begin{array}{c}95 \% \\
\text { Convidence } \\
\text { Interval }\end{array}$} & $r$ tabel & Ket \\
\hline 1 & $\begin{array}{l}\text { Kepemilikan } \\
\text { Manajerial }\end{array}$ & 3592 & 19 & 0.0950 & 0.0061 & 0.0052 & 0.0009 & 0.093 & 0.0967 & 0.0327 & Sig \\
\hline 2 & $\begin{array}{l}\text { Kepemilikan } \\
\text { Institusioal }\end{array}$ & 3459 & 20 & 0.0990 & 0.0066 & 0.0057 & 0.0009 & 0.097 & 0.1007 & 0.0333 & Sig \\
\hline 3 & $\begin{array}{l}\text { Ukuran Dewan } \\
\text { Direksi }\end{array}$ & 1444 & 7 & 0.0643 & 0.0072 & 0.0048 & 0.0024 & 0.059 & 0.0690 & 0.0516 & Sig \\
\hline 4 & $\begin{array}{l}\text { Ukuran Dewan } \\
\text { Komisaris }\end{array}$ & 1984 & 9 & 0.0714 & 0.0049 & 0.0045 & 0.0004 & 0.070 & 0.0722 & 0.0440 & Sig \\
\hline
\end{tabular}

